BULLETIN OF PNRPU. GEOLOGY. OIL \& GAS ENGINEERING \& MINING

ВЕСТНИК ПНИПУ. ГЕОЛОГИЯ. НЕФТЕГАЗОВОЕ И ГОРНОЕ ДЕЛО

ISSN 2224-9923

Volume/Tom 15 №21 2016

http://vestnik.pstu.ru/geo/

УДК 622.271 .3

Article / Статья

(C) PNRPU / ПНИПУ, 2016

\title{
DETERMINATION OF OPERATION PARAMETERS AND INDICATORS OF SURFACE MINERS IN MARBLE QUARRYING
}

\section{I.N. Sandrigailo, S.A. Arefiev, S.I. Chebotarev ${ }^{1}$ \\ Ural State Mining University (30 Kuibysheva str., Ekaterinburg, 620144, Russian Federation) \\ ${ }^{1}$ CJSC "Koyelgamramor" (1 Promyshlennaia str., Koelga, 456576, Russian Federation) \\ ОПРЕДЕЛЕНИЕ ПАРАМЕТРОВ И ПОКАЗАТЕЛЕЙ РАБОТЫ КАРЬЕРНЫХ КОМБАЙНОВ ПРИ ДОБЫЧЕ МРАМОРА}

\section{И.Н. Сандригайло, С.А. Арефьев, С.И. Чеботарев ${ }^{1}$}

Уральский государственный горный университет (620144, Россия, г. Екатеринбург, ул. Куйбышева, 30)

${ }^{1} 3 \mathrm{AO}$ «Коелгамрамор» (456576, Россия, Челябинская область, Еткульский район, с. Коелга, ул. Промышленная, 1)

Received / Получена: 03.10.2016. Accepted / Принята: 27.10.2016. Published / Опубликована: 02.12.2016

Key words:

deposit, marble, quarry, surface miner, engine power, operating weight, milling width, performance, schemes of work, regressional dependence, nomogram.
Ключевые слова:

месторождение, мрамор, карьер, комбайн, мощность двигателя, эксплуатационная масса, ширина фрезерования, производительность, схемы работы, регрессионные зависимости, номограмма.
The growth in marble quarrying requires the implementation at mining enterprises new high-performance equipment. In this connection, it is advisable to consider the possibility of use in the development of marble deposits surface milling miners. To improve the efficiency of their operation it is necessary develop a technique of operational definition of surface miners' basic parameters according to conditions existing at marble mining enterprises. Experience shows that when choosing miner's model the determination of its parameters can be carried out using regression dependences. As a result of processing initial information about technical characteristics of surface miners the dependences determining connection between milling width, engine power and operating weight were obtained.

In the largest Russian Koelginskoe marble deposit during 2014-2015 chronometer monitoring the work of surface milling miner Wirtgen 2500SM were conducted in different modes and conditions. In the study miner's speed was varied from 7 to $9 \mathrm{~m} / \mathrm{min}$ and cutting depth from 0.1 to $0.15 \mathrm{~m}$. Surface miner worked according to the shuttle scheme with a turn at the end of the site. Rock was loaded into dump trucks with carrying capacity of 25-30 tons. Processing of observational results allowed to get dependence for the operational definition of miner's performance in marble deposits developing. A nomogram for determining the engine power, weight and miner's operational performance with different milling widths was constructed.

Dependences obtained during the study can be used when selecting miner for a particular deposit, as well as when forecasting engine power, operating weight and performance of surface miner`s perspective models.

Рост объемов добычи мрамора требует внедрения на горных предприятиях нового высокопроизводительного оборудования. В связи с этим целесообразно рассмотреть возможность использования при разработке месторождений мрамора карьерных фрезерных комбайнов. Для повышения эффективности их эксплуатации необходимо разработать методику оперативного определения основных параметров комбайнов с учетом условий, существующих на предприятиях, добывающих мрамор. Опыт показывает, что при выборе модели комбайна расчет его параметров может осуществляться с использованием регрессионных зависимостей. В результате обработки исходной информации о технических характеристиках карьерных комбайнов получены зависимости, определяющие связь между шириной фрезерования, мощностью их двигателя и эксплуатационной массой. На крупнейшем в России Коелгинском месторождении мрамора в 2014-2015 гг. были проведены хронометражные наблюдения за работой карьерного фрезерного комбайна Wirtgen 2500SM при различных режимах и условиях эксплуатации. В ходе исследований скорость комбайна изменялась от 7 до 9 м/мин, а глубина фрезерования от 0,1 до 0,15 м. Комбайн осуществлял работу по схеме с разворотом в конце участка и по челноковой схеме. Погрузка горной массы производилась в автосамосвалы грузоподъемностью 25-30 т. Обработка результатов наблюдений позволила получить зависимости для оперативного определения производительности комбайна при разработке месторождения мрамора. Построена номограмма для определения мощности двигателя, эксплуатационной массы и производительности комбайнов с различной шириной фрезерования.

Полученные в ходе исследований зависимости можно использовать как при выборе комбайна для конкретного месторождения, так и при прогнозировании мощности двигателя, эксплуатационной массы и производительности перспективных моделей карьерных комбайнов.

Igor N. Sandrigailo - PhD of Technical Sciences, Associate Professor at the Department of Surface Mining (mob. tel.: +007912 635 2441 , e-mail: arefevsa@yandex.ru). Stepan A. Arefiev - PhD of Technical Sciences, Associate Professor at the Department of Mining (mob. tel.: +007 950 640 88 40, e-mail: arefevsa@yandex.ru). The contact person for correspondence.

Sergei I. Chebotarev - First Deputy Director General (mob. tel.: +007 91263524 41, e-mail: arefevsa@yandex.ru).

Сандригайло Игорь Николаевич - кандидат технических наук, доцент кафедры разработки месторождений открытым способом (моб. тел.: +007 9126352441, e-mail: arefevsa@yandex.ru).

Арефьев Степан Александрович - кандидат технических наук, доцент кафедры горного дела (моб. тел.: +007950 640 8840 , e-mail: arefevsa@yandex.ru). Контактное лицо для переписки.

Чеботарев Сергей Иванович - первый заместитель генерального директора (моб. тел.: +007 91263524 41, e-mail: arefevsa@yandex.ru). 


\section{Introduction}

Today one of the new areas of using marble is the production of facing slabs, marble products, marble microparticulate, uniform marble sand with narrow borders of particle size distribution, as well as decorative marble gravel. Manufacture's growth of these promising products requires an increase in the volume of mining and implementation of surface high-performance mining machines. In this regard, the possibility of using surface milling miners to operate marble deposits is considered.

Surface miners are successfully used in many countries around the world to operate deposits of coal, iron ore, bauxite, limestone, gypsum, shale, phosphate, salt, chalk, diamond [1-12]. However, there is not enough experience of their use for marble deposits' operating. Determination of the basic miner's parameters, which using is most advisable to operate such deposits, is conneced with a number of specific problems, primarily with the physical and mechanical marble's properties.

Despite the fact that many companies did the created and produced surface miners [13-18], the vast majority of todays operated machines on open-cut mining are "Wirtgen" company's miners. That is why it is advisable to analyze the parameters and performance of the miners' manufacturer.

The first "Wirtgen" company's miner (model 3000SM), designed to work in the open-cut minings, was released in 1980 and went through comprehensive testing. In 1983, the first instance of the miner's model 1900SM was sold to mining company in South Africa. Today 422 different miner's models work on the opencut minings all over the world.

Experience analysis of "Wirtgen" miners' use on the open-cut minings iduring thirty-five years allows making conclusions about the directions of their improvement and development. The first models of surface miner had three crawler tracks. This design was not good and today "Wirtgen" company's miners have four crawlers. Operating weight of modern miners is increased in 1.5-2.3 times in comparison with the first models. Engine power is increased by 1.3-1.7 times. As a result, cutting depth increased by 1.3-2.4 times, so it is possible to cut a strong rock, miner's performance increased significantly.

\section{Determination of engine power and miner's operating weight}

The cutting width is the most important parameter that influences on the surface miner's performance significantly. Its increasing can improve performance, but also requires to increse engine power and operating weight. At the same time, the engine power and the machine weight influence on its price and operating costs.

In the period from 1980 to 2016 "Wirtgen" company created and delivered to open-cut mining miners with 1900, 2100, 2200, 2500, 2600, 3000, $3500,3700,4200 \mathrm{~mm}$ cutting widths. They had operating weight from 27 to 204 tons and engine power from 298 to $1194 \mathrm{~kW}$.

The determination of miner's parameters for particular deposit can be performed using regression dependences. In order to obtain these dependences technical characteristics of modern surface miner were analyzed.

As a result of initial information processing regression dependences determining links between miner's cutting width $(B, \mathrm{~m})$, engine power $\left(N_{e}, \mathrm{~kW}\right)$ and an operating weight $(M, \mathrm{t})$ found were found.

The dependence power to determine the miner's engine, $\mathrm{kW}$, has the form

$$
N_{\mathrm{e}}=373.45 B^{0,81} \text {. }
$$

The value of the correlation coefficient is 0.999 .

Dependence to determine the miner's operating weight, $t$, has the form

$$
M=359.71-651.93 B^{-1} .
$$

The value of the correlation coefficient is 0.988 .

\section{Determination miner's performance in the extraction of marble}

For obtaining dependencies that can determine miners' performance during marble extraction in November 2014 and May 2015 on Koelginskoie deposit chronometer monitoring of the "Wirtgen" miner's 2500SM work were made. The optimum speed and cutting depth were determined, as well as the time needed to miner's maneuvers during his work.

Koelginskoie deposit's marble has a density from 2.63 to $2.73 \mathrm{~g} / \mathrm{cm}^{3}$. Its compressive strength is $24.30-111.60 \mathrm{MPa}$ (the average is $73.10 \mathrm{MPa}$ ).

Measurements made at Koelginskoie deposit showed that miner's rational working speed $V$ during marble cutting is $7-9 \mathrm{~m} / \mathrm{min}$, and the cutting depth $h$ is from 0.15 to $0.1 \mathrm{~m}$. The speed and the cutting depth increasing more then these values leads to increased cutters consumption, increased vibration, slippage caterpillars and products' fractional structure change. 
Combine carried out the working off sections by two main technological schemes: the scheme with a turning at the end of cutting area (Fig. 1a) and shuttling scheme (Fig. 1b) with return to the area beginning by idling [19-20].
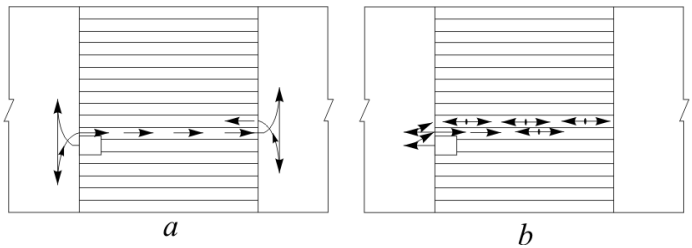

Fig. 1. Miner's work schemes: $a$ - with a turning at the end of cutting area, $b-$ and shuttling with return to the area beginning by idling

Thus, as chronometer monitoring showed time required miner's turning is $10 \mathrm{~min}$ and the idling miner's speed while returning to the top area is $20 \mathrm{~m} / \mathrm{min}$.

Mined rock is loaded at dumptruck of Belarusian Automobile Plant BelAZ-7540 with load capacity of 30 tons, as well as Chinese manufacturers' dumptrucks SHACMAN and SAMS with load capacity of 25 tons.

As the study results dependences were obtained which allow operatively to determine the operating marble deposits miners' performance $\left(Q, \mathrm{~m}^{3} / \mathrm{h}\right)$ of different cutting width $(B, \mathrm{~m})$. They were used for the calculation of "Wirtgen" miner's models 2500SM performance with marble extraction according to different schemes and areas of different lengths (see table).

Dependencies to determine miner's performance during marble extraction according to different schemes (if $V=7 \mathrm{~m} / \mathrm{min}$ and $h=0.1 \mathrm{~m}$ )

\begin{tabular}{|c|c|c|}
\hline $\begin{array}{c}\text { The area } \\
\text { length, } \mathrm{m}\end{array}$ & $\begin{array}{c}\text { Dependence to determine } \\
\text { the miner's performance, } \\
\mathrm{m}^{3} / \mathrm{h}\end{array}$ & $\begin{array}{c}\text { "Wirtgen" miner's } \\
\text { 2500SM performance, } \\
\mathrm{m}^{3} / \mathrm{h}\end{array}$ \\
\hline \multicolumn{3}{|c|}{ Scheme with a turning } \\
\hline 100 & $Q=24.20 \mathrm{~B}$ & 60.5 \\
\hline 200 & $Q=30.71 \mathrm{~B}$ & 76.77 \\
\hline 300 & $Q=33.73 \mathrm{~B}$ & 84.32 \\
\hline 400 & $Q=35.51 \mathrm{~B}$ & 88.77 \\
\hline 500 & $Q=36.61 \mathrm{~B}$ & 91.52 \\
\hline \multicolumn{3}{|c|}{ Shuttling scheme } \\
\hline $100-500$ & $Q=30.90 \mathrm{~B}$ & 77.25 \\
\hline
\end{tabular}

Using these dependences the nomogram was constructed that allows quickly to determine the engine power, operating weight and surface miner performance with different cutting widths during marble deposit operating (Fig. 2).

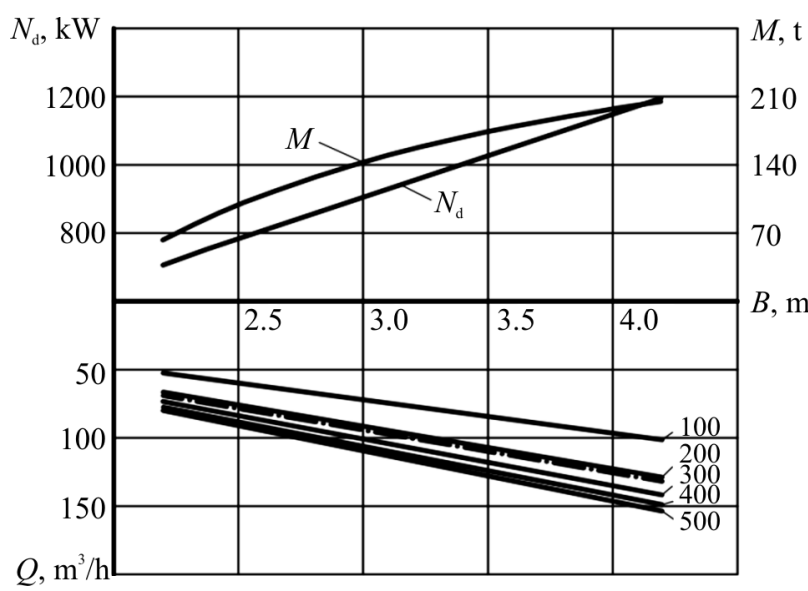

Fig. 2. The nomogram for determining the engine power $\left(N_{d}, \mathrm{~kW}\right)$, the operating weight $(M, \mathrm{t})$ and the miner performance $\left(Q, \mathrm{~m}^{3} / \mathrm{h}\right)$ with different cutting width $(B, \mathrm{~m})$ during operating marble deposit: $\longrightarrow$ scheme with miner turning, - - - shuttling scheme

However, it is necessary to consider that during miner operation there is lost time position associated with fuel and water refueling, worn cutters replacement, waiting dumptrucks, setting them for loading, etc. These time losses are accounted by using of the miner's utilization factor $K_{\mathrm{u}}$.

In this regard miner's shift operating performance $Q_{\mathrm{sh}} \mathrm{m}^{3} / \mathrm{cm}$, is determined by formula

$$
Q_{\mathrm{sh}}=Q T_{\mathrm{sh}} K_{\mathrm{u}},
$$

where $T_{\mathrm{sh}}-$ shift duration, $\mathrm{h} ; K_{\mathrm{u}}-$ miner's using factor for rock extraction.

\section{Conclusions}

An analysis of the surface miners technical parameters, as well as studies carried out on the Koelginskoe deposit, allowed to obtain regression dependencies which can be used in the operational definition of the miner different models' basic parameters and performance during operating marble deposits.

The nomogram for determining the miners' engine power, operating weight and performance with different cutting widths during operation on the scheme with a turning and shuttling scheme was constructed.

Offered dependence and nomogram may also be used in predicting the basic parameters and performance of perspective surface miners models. 


\section{References}

1. Anistratov K.Iu., Lutsishin S.V., Khartmann G. Kombain nepreryvnogo deistviia 2600SM na kar'ere tr. Iubileinaia AK "Almazy Rossii - Sakha" [Combine 2600SM of continuous action at the quarry Yubileinaya of PJSC "Diamonds of Russia - Sakha"]. Gornaia promyshlennost', 1994, no.1, pp.8-9.

2. Mohd Imran. Variation of production with time, cutting tool and fuel consumption of surface miner 2200 SM 3.8. International Journal of Technical Research and Applications, 2016, is. 01, pp.224-226.

3. Karlykhanov F.V., Levochkin V.F., Pankevich Iu.B., Khartmann G., Dolgushin V.D. Primenenie kar'ernogo kombaina Wirtgen 2100SM na dobyche fliusovogo syr'ia [Application of the career combine Wirtgen 2100SM in mining of raw flux materials]. Gornaia promyshlennost', 1998, no. 1, pp.38-39.

4. Itskov Ia.Iu., Iudin S.V., Leonenko A.N., Mainatashev A.S., Pikhler M., Pankevich Iu.B. Primenenie kar'ernogo kombaina Wirtgen 2200SM pri razrabotke Vostochno-Beiskogo kamennougol'nogo mestorozhdeniia [Application of the career combine Wirtgen 2200SM in development of East-Beiskoie coal field]. Gornaia promyshlennost ${ }^{\prime}, 2002$, no.2, pp.43-45.

5. Pikhler M., Pankevich Iu.B. Opyt dobychi izvestniaka kombainami Wirtgen Surface Miner v Indii [Limestone mining experience using combines Wirtgen Surface Miner in India]. Gornaia promyshlennost', 2003, no.3, pp.15-21.

6. Kozhevnikov V.A., Naboka N.V., Novoselov B.I., Pikhler M., Pankevich Iu.B. Kombainy Wirtgen Surface Miner na boksitovom rudnike Friia (Gvineia) [Combines Wirtgen Surface Miner in bauxite mine Fria (Guinea)]. Gornaia promyshlennost', 2004, no.1, pp.45-48.

7. Pikhler M., Guskov V., Pankevich Y., Pankevich M. Wirtgen Surface Miner 2200 SM pilot-industrial operation at the Dzhtgutinsky limestone open-pit mine. Russian Mining, 2005, no.3, pp.19-23.

8. Pikhler M., Pankevich Iu.B., Leu S.P. Kombainy Wirtgen Surface Miner na razrabotke mestorozhdenii fosforitov Respubliki Uzbekistan [Combines Wirtgen Surface Miner in the development of phosphorite deposits of the Republic of Uzbekistan]. Gornaia promyshlennost', 2009, no.1, pp.13-17.

9. Palei S.K., Karmakar N.C., Paliwal P., Schimm B. Optimization of productivity with surface miner using conveyor loading and truck dispatch system. International Journal of Research in Engineering and Technology, 2013, vol. 02, is.09, pp.393-396.
10. Pikhler M., Dikk F., Pankevich Iu.B. Kombainy Wirtgen Surface Miner na dobyche almazov na Aliaske [Wirtgen Surface Miners are mining diamonds in Alaska]. Gornaia promyshlennost', 2009, no.4, pp.14.

11. Dey K., Ghose A.K. Predicting "cuttability" with Surface Miners - a rockmass classification approach. Journal of Mines, Metals and Fuels, 2008, vol.56, no.5, 6, pp.85-92.

12. Dey K., Pathak K., Sen P. Environmental acceptability of Wirtgen Surface Miner for Indian surface coal mines. National Seminar on Mining in the New Millennium, 10-12 November 2000. Hyderabad, 2000, pp.136-142.

13. Dobychnye kombainy firmy Wirtgen serii SM [Mining combines by company Wirtgen of SM Series]. Gornaia promyshlennost', 1997, no.1, pp.51-52.

14. Kovalenko S.K., Shteintsaig R.M., Shenderov A.I., Aleksandrov A.A. K voprosu otsenki effektivnosti skhem gornogo proizvodstva na baze mashin tipa KSM [To the question of schemes effectiveness evaluating in mining on the basis of KSM type machines]. Gornaia promyshlennost', 1997, no.3, pp.23-29.

15. Kovalenko S.K. Effektivnost' primeneniia mashin tipa KSM $\mathrm{v}$ skhemakh potochnogo proizvodstva gornykh rabot [Effectiveness of KSM type machines in line production schemes of mining operations]. Gornaia promyshlennost', 1997, no.2.

16. Kombainy Vermeer dlia vyemki skal'nykh gornykh porod [Vermeer Combines for excavation of rock materials]. Gornaia promyshlennost', 2007, no.6, pp.60-61.

17. Knote T. Kompaniia Vermeer osvoila proizvodstvo samoi moshchnoi kar'ernoi vyemochnoi mashiny [The Vermeer company mastered production of the most powerful career winning machine]. Gornaia promyshlennost', 2013, no.6, pp.68-69.

18. Ghose A.K. New technology for Surface Mining in the 21st century - emerging role for Surface Miner. Journal of Mines Metals and Fuels, 2008, vol.56, no.3, 4, pp.41-43.

19. Pankevich Iu. B., Khartmann G. Tekhnologicheskie skhemy vedeniia gornykh rabot pri ispol'zovanii kombainov Wirtgen Surface Miner [Technological schemes of mining operations using combines Wirtgen Surface Miner]. Gornyi zhurnal, 1995, no.6, pp.30-33.

20. Pikhler M., Pankevich Iu.B. Tekhnologiia i skhemy vedeniia gornykh rabot pri ispol'zovanii kombainov 2100 i 2200 SM firmy Wirtgen $\mathrm{GmbH}$ [Technology and mining schemes using combines 2100 and 2200 SM company Wirtgen GmbH]. Gornaia promyshlennost', 2001, no.4, pp.13-16. 


\section{Список литературы}

1. Анистратов К.Ю., Луцишин С.В., Хартманн Г. Комбайн непрерывного действия $2600 \mathrm{SM}$ на карьере. Юбилейная АК «Алмазы России - Саха» // Горная промышленность. 1994. - № 1. - C. 8-9.

2. Mohd Imran. Variation of production with time, cutting tool and fuel consumption of surface miner $2200 \mathrm{SM} 3.8$ // International Journal of Technical Research and Applications. - 2016. Is. 01. - P. 224-226.

3. Применение карьерного комбайна Wirtgen 2100SM на добыче флюсового сырья / Ф.В. Карлыханов, В.Ф. Левочкин, Ю.Б. Панкевич, Г. Хартманн, В.Д. Долгушин // Горная промышленность. - 1998. - № 1. - С. 38-39.

4. Применение карьерного комбайна Wirtgen 2200SM при разработке Восточно-Бейского каменноугольного месторождения / Я.Ю. Ицков, С.В. Юдин, А.Н. Леоненко, А.С. Майнаташев, М. Пихлер, Ю.Б. Панкевич // Горная промышленность. -2002 . - № 2. - С. 43-45.

5. Пихлер М., Панкевич Ю. Б. Опыт добычи известняка комбайнами Wirtgen Surface Miner в Индии // Горная промышленность. - 2003. № 3. - С. 15-21.

6. Комбайны Wirtgen Surface Miner на бокситовом руднике Фрия (Гвинея) / В.А. Кожевников, Н.В. Набока, Б.И. Новоселов, М. Пихлер, Ю.Б. Панкевич // Горная промышленность. - 2004. - № 1. - С. 45-48.

7. Wirtgen Surface Miner 2200 SM pilotindustrial operation at the Dzhtgutinsky limestone open-pit mine / M. Pikhler, V. Guskov, Y. Pankevich, M. Pankevich // Russian Mining. - 2005. № 3. - P. 19-23.

8. Пихлер М., Панкевич Ю.Б., Леу С.П. Комбайны Wirtgen Surface Miner на разработке месторождений фосфоритов Республики Узбекистан // Горная промышленность. 2009. - № 1. - C. 13-17.

9. Optimization of productivity with surface miner using conveyor loading and truck dispatch system / S.K. Palei, N.C. Karmakar, P. Paliwal, B. Schimm // International Journal of Research in Engineering and Technology. - 2013. - Vol. 02, is. 09. - P. 393-396.
10. Пихлер М., Дикк Ф., Панкевич Ю.Б. Комбайны Wirtgen Surface Miner на добыче алмазов на Аляске // Горная промышленность. 2009. - № 4. - C. 15.

11. Dey K., Ghose A.K. Predicting «cuttability» with Surface Miners - a rockmass classification approach // Journal of Mines, Metals and Fuels. 2008. - Vol. 56, № 5, 6. - P. 85-92.

12. Dey K., Pathak K., Sen P. Environmental acceptability of Wirtgen Surface Miner for Indian surface coal mines // National Seminar on Mining in the New Millennium, 10-12 November 2000. Hyderabad, 2000. - P. 136-142.

13. Добычные комбайны фирмы Wirtgen серии SM // Горная промышленность. - 1997. № $1 .-$ C. 51-52.

14. К вопросу оценки эффективности схем горного производства на базе машин типа КСМ / С.К. Коваленко, Р.М. Штейнцайг, А.И. Шендеров, А.А. Александров // Горная промышленность. - 1997. - № 3. - С. 23-29.

15. Коваленко С.К. Эффективность применения машин типа КСМ в схемах поточного производства горных работ // Горная промышленность. - 1997. - № 2.

16. Комбайны Vermeer для выемки скальных горных пород // Горная промышленность. 2007. - № 6. - С. 60-61.

17. Кноте Т. Компания Vermeer освоила производство самой мощной карьерной выемочной машины // Горная промышленность. 2013. - № 6. - C. 68-69.

18. Ghose A.K. New technology for surface mining in the 21st century - emerging role for Surface Miner // Journal of Mines Metals and Fuels. - 2008. - Vol. 56, № 3, 4. - P. 41-43.

19. Панкевич Ю.Б., Хартманн Г. Технологические схемы ведения горных работ при использовании комбайнов Wirtgen Surface Miner // Горный журнал. - 1995. - № 6. C. $30-33$.

20. Пихлер М., Панкевич Ю.Б. Технология и схемы ведения горных работ при использовании комбайнов 2100 и 2200 SM фирмы Wirtgen $\mathrm{GmbH} / /$ Горная промышленность. 2001. - № 4. - C. 13-16.

Please cite this article in English as:

Sandrigailo I.N., Arefiev S.A., Chebotarev S.I. Determination of operation parameters and indicators of surface miners in marble quarrying. Bulletin of PNRPU. Geology. Oil \& Gas Engineering \& Mining, 2016, vol.15, no.21, pp.362-366. DOI: 10.15593/2224-9923/2016.21.8

Просьба ссылаться на эту статью в русскоязычных источниках следующим образом:

Сандригайло И.Н., Арефьев С.А., Чеботарев С.И. Определение параметров и показателей работы карьерных комбайнов при добыче мрамора // Вестник Пермского национального исследовательского политехнического университета. Геология. Нефтегазовое и горное дело. - 2016. - Т.15, №21. - C.362-366. DOI: 10.15593/2224-9923/2016.21.8 